\title{
ANALISIS KETAHANAN PANGAN DAN KARAKTERISTIK RUMAH TANGGA DENGAN KEJADIAN STUNTING
}

\author{
Nathasa Weisdania Sihite ${ }^{\bowtie}$, Yunita Nazarena, Firda Aris ka, Terati \\ Jurusan Gizi Poltekkes Kemenkes Palembang
}

\section{ARTICLE INFO \\ Article history}

Submitted : 2021-11-25

Revised : 2021-11-26

Accepted : 2021-11-29

\section{Keywords:}

Food security

Stunting

Toddlers

\section{Kata Kunci: \\ Ketahanan pangan Stunting \\ Balita} \begin{abstract}
Stunting is a condition of chronic growth failure experienced by toddlers that can cause children to experience difficulties in achieving optimal growth and development according to their age. Stunting can be minimized if the factors that affect stunting in the region can be controlled properly. Many factors are thought to influence the incidence of stunting, one of which is food security. If food insecurity occurs in a household, this can increase the proportion of stunting events that are increasing which can directly increase the national stunting incidence rate and will continue to be a major health problem in Indonesia. Indonesia. The purpose of this study was to analyze the relationship between household food security and household social factors with the incidence of stunting. The research was conducted in Palembang City, precisely at the 11 Ilir Health Center in Palembang. The research method used is a cross-sectional design. The determination of the research sample was carried out by purposive sampling based on the inclusion and exclusion criteria of the sample that had been determined in this study. The research sample was toddlers aged $0-59$ months totaling 40 people. Analy sis of the data used is chi-square with $=0.05$. In this study, it was found that there was a significant relationship between household food security $(\mathrm{p}=0.031)$, and household size $(\mathrm{p}=0.000)$ with the incidence of stunting, while for the variable mother's age $(p=0.393)$ and mother's education level $(p=0.283)$ is known to have no significant relationship with the incidence of stunting. Household food security is directly related to the incidence of stunting, families in households who are not food insecure tend to have children under five who are classified as stunting, this is due to the lack of nutritional intake received both in terms of quantity and quality and does not meet the nutritional adequacy standard for stunting toddlers. It is hoped that to reduce the incidence of stunting, the government needs to add a local food-based work program in reducing the incidence of stunting.
\end{abstract}

Stunting adalah kondisi gagal tumbuh kronis yang dialami balita yang dapat menyebabkan anak mengalami kesulitan dalam mencapai pertumbuhan dan perkembangan yang optimal sesuai usianya. Stunting dapat diminimalisir jika faktor y ang mempengaruhi stunting di wilay ah dap at dikendalikan dengan baik. Bany ak faktor yang diduga dapat mempengaruhi kejadian stunting, salah satuny a ketahanan pangan, jika kerawanan pangan terjadi dalam suatu rumah tangga hal ini dapat meningkatkan proporsi kejadian stunting yang semakin meningkat yang secara langsung dapat meningkatkan angka kejadian stunting nasional meningkat dan akan terus menjadi masalah utama kesehatan di Indonesia. Tujuan penelitian ini adalah untuk menganalisis hubungan antara ketahanan pangan rumah tangga dan karakteristik rumah tangga berupa faktor sosial rumah tangga dengan kejadian stunting. Penelitian dilakukan di Kota Palembang, tepatnya di Puskesmas 11 Ilir Palembang. Metode penelitian yang digunakan adalah rancangan cross-sectional. Penentuan sampel penelitian dilakukan secara purposive sampling berdasarkan kriteria inklusi dan eksklusi sampel yang telah ditentukan dalam penelitian ini. Sampel penelitian adalah balita usia $0-59$ bulan yang berjumlah 40 orang. Analisis data y ang digunakan adalah chi-square dengan $\alpha=0,05$. Pada penelitian ini diketahui bahwa terdapat hubungan y ang signifikan antara ketahanan pangan rumah tangga $(p=0,031)$, dan ukuran rumah tangga $(p=0,000)$ dengan kejadian stunting, sedangkan untuk variabel umur ibu $(\mathrm{p}=0,393)$ dan tingkat pendidikan ibu $(\mathrm{p}=0,283)$ diketahui tidak memiliki hubungan yang signifikan den gan kejadian stunting. Ketahanan pangan rumah tangga berhubungan langsung dengan kejadian stunting, keluarga dalam rumah tangga yang tidak tahan pangan cenderung memiliki balita yang tergolong stunting, hal ini disebabkan karena kurangny a asupan zat gizi y ang diterima baik dari segi kuantitas maupun kualitas dan tidak memenuhi standar kecukupan zat gizi balita stunting, diharapkan dalam upaya mengurangi angka kejadian stunting pemerintah perlu menambahkan program kerja berbasis pangan lokal dalam menurunkan angka kejadian stunting. 


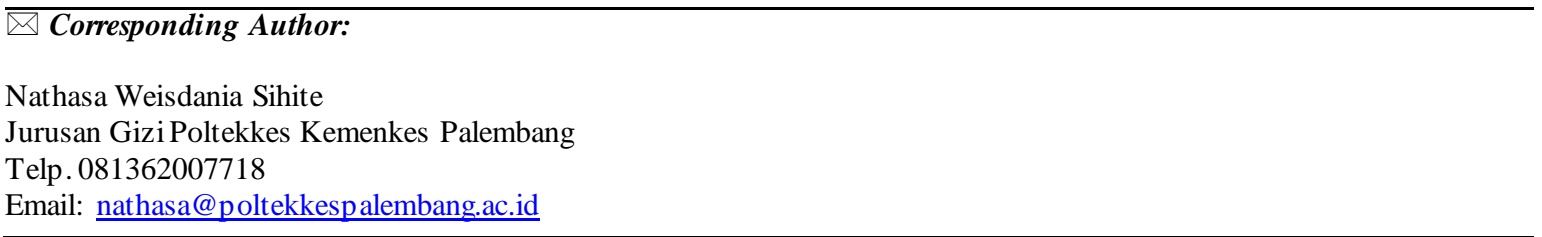

\section{PENDAHULUAN}

Gagal tumbuh atau yang lebih dikenal dengan istilah stunting merupakan kegagalan tumbuh kembang yang dialami anak usia di bawah lima tahun akibat dari defisiensi zat gizi kronis dan kejadian tersebut berulang terutama pada masa emas 1000 hari pertama kehidupan (Mustika \& Syamsul, 2018).

Indikator ketika balita dikatakan stunting adalah jika z-score tinggi badan menurut umur (TB/U) bernilai -2SD (Musyayadah \& Adinings ih, 2019) Berdasarkan hasil dari Riset Kesehatan Dasar Tahun 2018, diinformasikan bahwa prevalensi stunting di Indonesia berjumlah $30,8 \%$, persentase tersebut mengalami penurunan dalam prevalensi kasus stunting di tahun 2017 dengan penurunan sebesar 6,4 \% (Amalia \& Adriani, 2019). Berdasarkan data Pemantauan Status Gizi (PSG) tahun 2017, Provinsi Sumatera Selatan persentase stunting adalah $22,8 \%$ sedangkan Kota Palembang sebesar 14,5\%. Berdasarkan kelompok umur dimana kelompok us ia $24-59$ bulan lebih tinggi (22,8\%) dibandingkan dengan usia $0-23$ bulan (14,3\%) (Riskesdas, 2018). Berdasarkan data (Badan Pusat Statistik Provinsi Sumatera Selatan, 2019) menginfokan bahwa prevalensi stunting di Puskesmas 11 Ilir 10,9\% (117 kasus) dan berdasarkan data tiga tahun terakhir dimana prevalensi kejadian stunting di Puskesmas 11 Ilir tinggi dimulai tahun 2015 (12,0\% dengan 135 kasus), 2016 (16,4\% dengan 162 kasus) dan tahun 2017 $(10,9 \%)$ sehingga menjadi prioritas dalam menanggulangi masalah stunting tersebut.

Status gizi balita merupakan indikator yang baik untuk mendapatkan dan mengetahui status penyerapan/absorpsi pangan di tingkat rumah tangga. Dilaporkan menurut Badan Ketahanan Pangan Provinsi Sumsel Tahun 2016, bahwa faktor yang mempengaruhi status gizi seorang balita adalah situasi ketahanan pangan. Status gizi yang tidak baik akan mencerminkan ketahanan pangan yang kurang baik juga. Dilaporkan dari 140.043 jumlah bayi lahir tahun 2010 di Sumsel, terdapat 220 bayi yang lahir dengan berat badan rendah $(0,15 \%)$ dan 161 bayi berstatus gizi buruk $(0,11 \%)$, kriteria gizi kurang pada balita ini dapat menjadi penyebab dari kerawanan pangan, baik pada prioritas I, II dan III untuk ditanggulangi (Kementerian Pertanian, 2016).

Level ketahanan rumah tangga dapat dipengaruhi oleh berbagai macam faktor baik yang berasal dari rumah tangga itu sendiri maupun faktor yang berasal dari luar rumah tangga. Ketahanan pangan secara realistis dapat diukur dengan berbagai macam indicator salah satunya adalah tingkat konsumsi rumah tangga dan status gizi (Sihite \& Tanziha, 2021). Untuk mengembangkan pola konsumsi pangan sangat diperlukan pengetahuan, kemampuan dan keterampilan dalam memilih jenis bahan pangan yang disesuaikan dengan pola kebiasaan masyarakat setempat. Berdasarkan penelitian yang dilakukan oleh Omotesho et al., (2019) yang meneliti tentang ketahanan pangan dan kemiskinan dari Rumah tangga pedesaan di Kwara State, Nigeria. Hasil penelitian mengungkapkan bahwa $66 \%$ sampel rumah tangga berada di bawah garis kemiskinan (Omotesho et al., 2019). Berdasarkan latar belakang tersebut, oleh karena itu diperlukan suatu aspek untuk melihat hubungan konsumsi pangan dan hubungannya dengan tingkat kesejahteraan hidup balita, khususnya balita yang berada dalam kategori stunting. Pengaruh konsumsi pangan terhadap status gizi anak balita tidak hanya dapat dinilai dari aspek kuantitasnya saja, melainkan juga dapat dinilai secara langsung dari aspek kualitasnya (Prasetyo et al., 2013). Hadinsyah dan Aries (2016), mengungkapkan bahwa terdapat tiga dari sepuluh anak balita Indonesia mengalami gizi kurang (KEP), dan tiga dari sepuluh wanita hamil mengalami kurang energi kronik (KEK), serta enam dari sepuluh keluarga berpotensi mengalami rawan pangan (Food Insecurity) dikarenakan ketidakmampuan keluarga tersebut dalam memenuhi dua pertiga dari kebutuhannya (Hardinsyah \& Aries, 2016).

Hasil penelitian Khomsan et al. (2013) menyatakan bahwa masih banyak terdapat masalah gizi yang terjadi pada anak balita di masyarakat adat Kasepuhan Ciptage lar yaitu prevalensi wasting (12.5\%) dan prevalensi stunting $(31 \%)$ yang masuk kategori tergolong tinggi dan dinyatakan sebagai masalah 
kesehatan masyarakat menurut klasifikasi WHO (Khomsan et al., 2013). Palembang merupakan kota metropolitan yang mempunyai jumlah penduduk yang besar. Sumber daya pangan di Kota Palembang juga cukup bervariasi. Untuk mengetahui ketahanan pangan rumah tangga balita stunting baik dari aspek kuantitas maupun kualitas, maka diperlukan berbagai macam data seperti data konsumsi pangan rumah tangga dan data sosial ekonomi rumah tangga. Data tersebut akan dijadikan sebagai acuan dalam mengetahui gambaran analis is ketahanan pangan rumah tangga balita stunting di Puskesmas 11 Ilir. Sampai dengan saat ini penelitian-penelitian terdahulu hanya terpusat dalam meneliti tentang stunting, masih sangat minim penelitian yang melihat hubungan ketahanan pangan dengan kondisi stunting yang terjadi dimasyarakat. Tujuan dari penelitian ini adalah ingin melakukan pemantauan dan menganalis is secara khusus mengenai ketahanan pangan rumah tangga balita stunting serta karakteristik rumah tangga berupa faktor sosial pendukung lainnya seperti umur ibu rumah tangga, pendidikan ibu rumah tangga, ukuran rumah tangga, yang berhubungan dengan kejadian stunting pada anak balita di Kota Palembang. Penelitian ini nantinya dapat memberikan informasi bagi pemerintah daerah dan pusat dalam menanggulangi masalah kesehatan anak balita yang masih menjadi masalah besar di Indonesia seperti wasting dan stunting.

\section{METODE PENELITIAN \\ Jenis Penelitian}

Desain dalam penelitian ini adalah penelitian observasional analitik dengan menggunakan rancangan cross sectional study.

\section{Lokasi dan Waktu Pene litian}

Penelitian ini berlokasi di Puskesmas 11 Ilir Palembang, Kota Palembang. Penelitian dilaksanakan pada bulan Juni - November 2020.

\section{Populasi dan Sampel}

Populasi penelitian adalah Balita usia 0 - 59 bulan yang terdata di wilayah cakupan Puskesmas 11 Ilir. Penentuan sampel penelitian dilakukan secara purposive sampling berdasarkan kriteria stunting yang telah ditentukan dalam penelitian ini. Sampel ditentukan berdasarkan Rumus Lemeshow berdasarkan perhitungan sampel, skrining dan seleksi sesuai kriteria inklusi dan eksklusi didapatkanlah jumlah sampel penelitian ini sebanyak 40 sampel (Lemeshow et al., 1997).

\section{Pengumpulan Data}

Data dikumpulkan melalui wawancara, observasi dan pengukuran langsung. Data karakteristik rumah tangga meliputi: umur orang tua, umur balita, jumlah anggota rumah tangga, tingkat pendidikan dan pengeluaran rumah tangga dikumpulkan dengan metode wawancara terstruktur yaitu dengan kuesioner.

Data konsumsi pangan dan status gizi dikumpulkan melalui wawancara dan pengukuran langsung dengan menggunakan metode kuesioner SQFF (Semi Quantitative Food Frequency). Data stunting diperoleh melalui pengukuran langsung menggunakan infantometer dan microtoise, data riwayat asupan energi dan protein diperoleh melalui wawancara menggunakan form SQFF.

\section{Pengolahan dan Analis is Data}

Pengolahan data dilakukan secara statistik dengan menggunakan perangkat lunak komputer SPSS. Analis is data dilakukan secara univariat dan bivariat. Analisis univariat dilakukan untuk melihat sebaran distribusi frekuensi variabel penelitian yang akan dianalisis, sedangkan analis is bivariat dipakai untuk mengetahui hubungan-hubungan antar variabel penelitian yang dilakukan dengan analisis Chi-Square. Jika p-value $<0.05$ maka perhitungan secara statistik yang digunakan yaitu Continuity Correction menunjukkan bahwa adanya hubungan antara variabel independen dengan variabel dependen. Penelitian ini menggunakan taraf signifikan 95\%.

\section{HASIL PENELITIAN \\ Analisis Univariat}

Karakteristik rumah tangga responden pada penelitian ini adalah usia ibu, ukuran rumah tangga, tingkat pendidikan ibu, tingkat kecukupan gizi rumah tangga, dan ketahanan pangan rumah tangga. Data karakteristik responden penelitian dapat dilihat pada Tabel 1.

Secara umum, data distribusi responden ibu balita yang memiliki balita umur $0-59$ bulan, berkisar di rentang umur dewasa awal yaitu berkisar 18 - 39 tahun dengan persentase 
$82,5 \%$. Jika dilihat dari rentang umur, usia ibu yang mempunyai balita tergolong dalam usia produktif.

Tabel 1. Karakte ris tik responden penelitian

\begin{tabular}{lcc}
\hline Karakteris tik & $\mathbf{n}$ & $\mathbf{\%}$ \\
\hline Usia Ibu (Tahun) & & \\
Dewasa Awal & 33 & 82,5 \\
Dewasa Madya & 7 & 17,5 \\
Ukuran Rumah Tangga & & \\
> 4 orang & 28 & 70 \\
< 4 orang & 12 & 30 \\
Tingkat Pendidikan Ibu & & \\
SD & 10 & 25 \\
SMP & 9 & 22,5 \\
SMA & 20 & 50 \\
PT & 1 & 2,5 \\
Usia Balita (Bulan) & & \\
0-12 & 7 & 17,5 \\
13-24 & 8 & 20 \\
25-36 & 10 & 25 \\
37-59 & 15 & 37,5 \\
\hline \multicolumn{1}{c}{ Total } & $\mathbf{4 0}$ & $\mathbf{1 0 0}$ \\
\hline
\end{tabular}

Analisis Bivariat

Hasil analis is bivariat dari penelitian ini yaitu hubungan karakteristik rumah tangga (umur ibu, ukuran rumah tangga, tingkat pendidikan ibu) dan ketahanan pangan rumah tangga yang dianalisis hubungannya dengan kejadian stunting. Data hubungan antar variabel yang diteliti dapat dilihat pada Tabel 2 . Berdasarkan analis is uji Chi-Square terdapat hubungan yang bermakna $(p<0.05)$ antara ukuran rumah, dan Ketahanan pangan rumah tangga.

\section{PEMB AHASAN}

Hubungan umur ibu dengan stunting

Hasil analisis uji statistik pada Tabel 2. menunjukkan bahwa tidak terdapat hubungan yang signifikan (bermakna) antara usia ibu dengan kejadian stunting pada anak balita di wilayah kerja Puskesmas 11 Ilir Palembang, hal ini dibuktikan dengan hasil $\mathrm{p}$ value $>0.05$ yaitu $\mathrm{p}$ value $=0.393$. Usia sangat mempengaruhi pola asuh seorang ibu dalam memilih makanan yang baik bagi anaknya ketika seorang ibu telah siap dan matang dalam mengolah pemikiran dan sikapnya dalam mengasuh anak, hal ini akan membuat seorang ibu juga dapat secara lebih bijak dalam menyediakan kebutuhan gizi anaknya baik dari kualitas maupun kuantitas makanannya.

Tabel 2. Analisis Hubungan Antara Usia Ibu, Ukuran Rumah Tangga, Tingkat Pendidikan Ibu, dan Ketahanan Pangan Rumah Tangga

\begin{tabular}{|c|c|c|c|c|c|c|c|}
\hline \multirow{3}{*}{ Variabel } & \multicolumn{4}{|c|}{ Status Gizi } & \multirow{2}{*}{\multicolumn{2}{|c|}{ Total }} & \multirow{3}{*}{ p-value } \\
\hline & \multicolumn{2}{|c|}{ Stunting } & \multicolumn{2}{|c|}{ Tidak Stunting } & & & \\
\hline & $\mathbf{n}$ & $\%$ & $\mathbf{n}$ & $\%$ & $\mathbf{n}$ & $\%$ & \\
\hline \multicolumn{8}{|l|}{ Umur Ibu (Tahun) } \\
\hline Dewasa awal $(18-39)$ & 21 & 63,6 & 12 & 36,4 & 33 & 100 & \multirow[t]{2}{*}{0,393} \\
\hline Dewasa madya $(40-59$ & 6 & 85,7 & 1 & 14,3 & 7 & 100 & \\
\hline \multicolumn{8}{|l|}{ Ukuran Rumah Tangga } \\
\hline$>4$ orang (besar) & 5 & 31,3 & 11 & 68,8 & 16 & 100 & \multirow{2}{*}{0,000} \\
\hline$<4$ orang (kecil) & 22 & 91,7 & 2 & 8,3 & 24 & 100 & \\
\hline \multicolumn{8}{|l|}{ Tingkat Pendidikan Ibu } \\
\hline SD & 7 & 70 & 3 & 30 & 10 & 100 & \multirow{4}{*}{0,283} \\
\hline SMP & 8 & 88,9 & 1 & 11,1 & 9 & 100 & \\
\hline SMA & 11 & 55 & 9 & 45 & 20 & 100 & \\
\hline PT & 1 & 100 & 0 & 0 & 1 & 100 & \\
\hline \multicolumn{8}{|l|}{ Ketahanan Pangan RT } \\
\hline Tidak Tahan Pangan $(<90 \%)$ & 26 & 74,3 & 9 & 25,7 & 35 & 100 & \multirow[t]{2}{*}{0,031} \\
\hline Tahan Pangan $(>90 \%)$ & 1 & 20 & 4 & 80 & 5 & 100 & \\
\hline Total & 27 & 67,5 & 13 & 32,5 & 40 & 100 & \\
\hline
\end{tabular}


Pada penelitian ini rentang usia ibu berada di umur 18 - 39 tahun, dimana merupakan usia matang untuk bereproduksi dan berpikir secara dewasa. Pada hasil analisis statistik menunjukkan tidak ada hubungan bermakna antara usia ibu dengan kejadian stunting. Hal ini juga sejalan dengan penelitian yang dilakukan oleh (Nirmala et al., 2018) dimana dalam hasil penelitiannya didapatkan bahwa tidak ada hubungan yang signifikan antara usia Ibu dengan kejadian stunting pada balita di Kecamatan Sawah Besar Kota Jakarta Pusat. Pada usia 18 - 39 tahun, sudah diperkirakan memiliki kedewasaan dalam mengasuh, merawat dan membesarkan buah hatinya, akan tetapi tidak menutup kemungkinan dalam usia tersebut seorang ibu dikarenakan kesibukannya, aktivitasnya dan berbagai macam faktor lainnya menjadi belum terlalu paham dalam menerapkan pengetahuan khususnya dalam pendidikan gizi pada balita (Hayyudini et al., 2017). Hal ini juga sejalan dengan penelitian yang dilakukan oleh Nirmala et al.,(2018), dimana tidak terdapat hubungan yang signifikan antara usia ibu dengan kejadian stunting, pengetahuan gizi ibu jauh lebih memberikan kontribusi yang bermakna dalam menurunkan angka stunting jika dibandingkan dengan usia ibu. Hal ini dikarenakan, kebanyakan ibu ibu memberikan makan kepada balita tanpa memperhatikan kebutuhan zat gizinya, hal ini mengakibatakan asupan yang diterima oleh balita menjadi kurang baik baik dari segi kualitas maupun kuantitasnya (Nirmala et al., 2018).

\section{Hubungan Ukuran Rumah Tangga dengan Stunting}

Hasil analisis uji statistik pada Tabel 2. Menunjukkan bahwa terdapat hubungan yang signifikan antara ukuran rumah tangga dengan kejadian stunting pada penelitian ini, hal ini dibuktikan dengan hasil $\mathrm{p}$ value $<0.05$ yaitu $\mathrm{p}$ value $=0.000$. Pada penelitian ini jumlah anggota keluarga pada responden penelitian ini adalah termasuk dalam ukuran rumah tangga besar, dimana memiliki anggota keluarga yang $>4$ orang.

Dalam keluarga dengan anggota keluarganya yang terdiri dari $>4$ orang, biasanya anaknya lebih pendek dari pada dengan keluarga yang mempunya anggota keluarga $<4$ orang, hal ini dapat disebabkan karena anak bisa kurang mendapat perhatian yang ekstra dari aktivitas pola asuh orang tuanya, sehingga dengan minimnya perawatan dan perhatian terhadap anak tersebut mengakibatkan status gizinya juga kurang intens diperhatikan (Ibrahim \& Faramita, 2015). Hal ini juga sejalan dengan yang dilakukan oleh Sihite dan Tanziha (2021), dimana terdapat hubungan yang signifikan antara jumlah anggota rumah tangga dengan tingkat ketahanan pangan dalam suatu rumah tangga (keluarga), dimana jika semakin banyak anggota keluarga akan berdampak langsung terhadap jumlah pengeluaran yang dikeluarkan untuk memenuhi kebutuhan pangannya(Sihite \& Tanziha, 2021).

Hal ini juga sejalan dengan penelitian yang dilakukan oleh Aini (2018) yang menyatakan peluang anak memiliki status gizi yang buruk akan lebih besar persentasenya pada keluarga yang mempunyai banyak anak dan tergolong da lam status ekonomi yang rendah, di samping itu jika ibu dalam keluarga tersebut terpaksa harus bekerja untuk memenuhi kebutuhan keluarganya akan lebih sangat mempengaruhi pemenuhan gizi balita yang diasuh dalam keluarga tersebut (Aini et al., 2018). Anak memerlukan perhatian dan makanan yang sesuai dengan kebutuhannya, namun kondisi keluarga yang ekonominya kurang dan ditambah dengan jumlah anggota keluarganya yang banyak akan sangat sulit dalam memenuhi kebutuhan hidupnya baik itu kebutuhan sandang dan pangan (Karundeng et al., 2015). Hal ini sejalan dengan penelitian yang dilakukan pada responden yang ada di wilayah kerja Puskesmas 11 Ilir, dimana rumah tangga dengan anggota keluarga yang besar lebih dominan, hal ini tentu saja dapat mempengaruhi pengalokasian sumber kebutuhan hidup khususnya dalam memenuhi kebutuhan pangannya, yang dapat mengakibatkan asupan gizi yang diberikan tidak memenuhi kecupan gizi yang seharusnya sehingga dapat berdampak terhadap status gizi yang tidak baik bagi balita.

\section{Hubungan Tingkat Pendidikan Ibu dengan Stunting}

Berdasarkan uji statistik dengan uji $C h i$ Square didapatkan nilai $p=0,283(\leq 0,05)$. Hal ini menunjukkan bahwa tidak ada hubungan yang bermakna antara pendidikan Ibu dengan kejadian stunting pada balita di Puskesmas 11 Ilir. Hasil penelitian ini sejalan dengan 
penelitian Rahmawati (2020) yang menunjukkan bahwa tidak ada hubungan bermakna antara pendidikan Ibu dengan kejadian stunting pada balita. Pendidikan ibu merupakan hal dasar bagi tercapainya gizi balita yang baik. Tingkat pendidikan ibu tersebut terkait dengan kemudahan ibu dalam menerima informasi tentang gizi dan kesehatan dari luar. Ibu dengan tingkat pendidikan yang lebih tinggi akan lebih mudah menerima informasi dari luar, dibandingkan dengan ibu yang memiliki tingkat pendidikan lebih rendah (Rahmawatiet al., 2020).

Tingkat pendidikan pada keluarga miskin sebagian besar dalam kategori rendah, hal ini dikarenakan keterbatasan ekonomi yang dialami sehingga mereka tidak mampu melanjutkan pendidikan pada jenjang yang lebih tinggi (Ni'mah. \& Lailatul, 2015). Dalam penelitian ini, mayoritas ibu yang memiliki tingkat pendidikan menengah yaitu SMA, seperti penelitian sebelumnya dije laskan bahwa pendidikan rendah tidak selalu memiliki balita dengan masalah stunting yang lebih banyak daripada ibu dengan tingkat pendidikan lebih tinggi. Hal ini dikarenakan tingkat pendidikan bukan menjadi penyebab utama dari kejadian stunting yang dialami balita, masih banyak determinan faktor yang dapat mempengaruhi terjadinya masalah kurang gizi, khususnya wasting dan stunting pada keluarga miskin.

\section{Hubungan Ketahanan Pangan Rumah Tangga dengan Stunting}

Hasil analisis chi-square menunjukkan bahwa rumah tangga dengan kategori rawan pangan (tidak tahan pangan) lebih banyak terdapat pada kelompok kasus (balita stunting) yakni 74,3\%. Hasil analisis menggunakan uji chi-square menunjukkan terdapat hubungan yang signifikan antara ketahanan pangan rumah tangga dengan stunting pada balita $(\mathrm{p}=0,031)$. Ketahanan pangan terbagi menjadi dua aspek, yaitu kuantitatif dan kualitatif. Dalam mengukur ketahanan pangan secara kuantitatif dapat diukur berdasarkan berdasarkan tingkat kecukupan energi rumah tangga, dimana jika tingkat kecukupan energinya $<90,0 \%$ (tidak tahan pangan), sedangkan jika tingkat kecukupan energinya $\geq 90,0 \%$ (tahan pangan (Tanziha, 2011). Sedangkan untuk mengukur ketahanan pangan dari aspek kualitatif dapat diukur melalui banyak faktor seperti berdasarkan tingkat kelaparan, ketersediaan pangan, pengeluaran dan pendapatan rumah tangga (Devi et al., 2020). Hal ini sejalan dengan penelitian yang dilakukan oleh Masrin yang menyatakan bahwa bahwa ketahanan pangan rumah tangga sebagai faktor risiko yang signifikan terhadap kejadian stunting pada baduta usia $6-23$ bulan. Baduta yang berada pada rumah tangga rawan pangan mempunyai risiko 2,62 kali lebih besar menderita stunting dibandingkan dengan baduta pada rumah tangga yang tahan pangan (Masrin et al., 2014).

$$
\text { Pangan merupakan salah satu }
$$

kebutuhan dasar manusia. Jika kebutuhan tersebut tidak terpenuhi, baik jumlah maupun mutunya pada tingkat individu dan rumah tangga akan mengganggu tercapainya kualitas hidup sehat, aktif, dan berkesinambungan, dan nantinya dapat menimbulkan masalah kesehatan dan gizi. Balita stunting merupakan salah satu masalah gizi yang kronis yang masih menjadi tujuan dari Pemerintah dalam menanggulangi masalah stunting yang ada di Indonesia, stunting dapat disebabkan oleh akses dan keterjangkauan terhadap pangan yang relatif masih rendah dan sulit diakses.

Pada penelitian ini karakteristik dari rumah tangga responden berada dalam kategori rumah tangga yang menengah ke bawah, di samping masalah sosial ekonomi, pengaruh pengetahuan dan kebiasaan makan juga menjadi faktor utama terjadinya stunting di wilayah kerja Puskesmas 11 Ilir Palembang. Rumah tangga yang tidak dapat memenuhi kecukupan gizi anggota keluarganya baik dari aspek kuantitas dan kualitas, akan berdampak langsung terhadap kebutuhan gizi dari balita, sehingga kasus kurang gizi dan gagal tumbuh seperti stunting dapat terjadi. Hal ini sejalan dengan penelitian yang dilakukan oleh Safitri tentang hubungan ketahanan pangan keluarga dan pola konsumsi keluarga petani menunjukkan bahwa tingkat ketahanan pangan keluarga yang tergolong tidak tahan pangan disebabkan oleh berbagai macam faktor seperti adanya kekhawatiran akan habisnya persediaan pangan, tidak mempunyai pengetahuan gizi khususnya dalam menyediakan makanan bergizi seimbang untuk rumah tangga, ketidakmampuan memperoleh makanan pokok yang terkadang bergantung dari pemberian orang lain, dan keterbatasan finansial yang dihadapi oleh rumah tangga (Alfarisi et al., 2020). Ketahanan pangan di rumah tangga mendukung tingkat konsumsi balita, baik energi 
dan protein. Rendahnya tingkat konsumsi balita dapat mempengaruhi pertumbuhan dan perkembangan pada balita, dan jangka panjangnya dapat menyebabkan masalah gagal tumbuh sepertiwasting dan stunting.

\section{KESIMPULAN DAN SARAN}

Stunting merupakan masalah yang masih menjadi pusat perhatian di Indonesia. Banyak faktor yang mempengaruhi kejadian stunting salah satunya adalah ketahanan pangan rumah tangga dan faktor sosial lainnya. Ketahanan pangan di sektor rumah tangga merupakan langkah awal dalam mencegah terjadinya stunting di tingkat keluarga. Hasil penelitian didapatkan bahwa ketahanan pangan rumah tangga sangat mempengaruhi kejadian stunting pada sampel penelitian, selain itu karakteristik rumah tangga yang dilihat dari segi jumlah ukuran rumah tangga juga memberikan pengaruh besar terhadap kejadian stunting, dimana jika semakin banyak anggota rumah tangga di dalam suatu keluarga, secara tidak langsung berpengaruh terhadap kontribusi asupan konsumsi keluarga, hal ini dapat menimbulkan pembagian kecukupan gizi pada balita stunting menjadi tidak optimal.

Upaya dalam mencegah serta menanggulangi stunting harus dimulai dari memperhatikan ketercukupan kebutuhan pangan di tingkat keluarga, diperlukan program dan inovasi baru berbasis peningkatan pangan lokal dan pemberdayaan keluarga yang dapat meningkatkan ketahanan pangan rumah tangga yang nantinya diharapkan, ketahanan pangan tangga secara langsung dapat mengurangi angka kejadian stunting di masyarakat.

\section{DAFTAR PUSTAKA}

Aini, E. N., Nugraheni, S. A., \& Pradigdo, S. F. (2018). Faktor Yang Mempengaruhi Stunting Pada Balita Usia 24- 59 Bulan Di Puskesmas Cepu Kabupaten Blora. Jurnal Kesehatan Masyarakat, Volume 6, 454-461.

Alfarisi, R., Yuniastini, Y., Pinilih, A., \& Jauhari, P. N. O. (2020). Kebiasaan Sarapan Pagi dengan Prestasi Belajar Siswa SD Negeri 01 Rajabasa Bandar Lampung. Jurnal Ilmiah Kesehatan Sandi Husada, 11(1). https://doi.org/ 10.35816/jiskh.v11i1.237.

Amalia, S. M. K., \& Adriani, M. (2019). Hubungan antara Kebiasaan sarapan dengan Status Gizi pada siswa SMP Negeri 5 Banyuwangi. Amerta Nutrition, 3(4).

https://doi. org/10.20473/amnt.v3i4.2019. 212-217.

Badan Pusat Statistik Provinsi Sumatera Selatan. (2019). Provinsi Sumatera Selatan Dalam Angka 2019. In Badan Pusat Statistik Provinsi Sumatera Selatan.

Devi, L. Y., Andari, Y., \& Wihastuti, L. (2020). Model Sosial-Ekonomi Dan Ketahanan Pangan Rumah Tangga Di Indonesia Socio-Economic Model and Households' Food Security in Indonesia. Jurnal Ekonomi Dan Pembangunan, 28, 27-39.

Hardinsyah, H., \& Aries, M. (2016). Jenis Pangan Sarapan Dan Perannya Dalam Asupan Gizi Harian Anak Usia 6-12 Tahun Di Indonesia. Jurnal Gizi Dan Pangan, $\quad 7(2) . \quad$ https://doi.org/ 10.25182/jgp.2012.7.2.89-96.

Hayyudini, D., Suyatno, \& Darmawan, Y. (2017). Hubungan Karakteristik Ibu, Pola Asuh Dan Pemberian Imunisasi Dasar Terhadap Status Gizi Anak Usia 12-24 Bulan (Studi Di Wilayah Kerja Puskesmas Kedungmundu Kota Semarang Tahun 2017). Jurnal Kesehatan Masyarakat (e-Journal), 5(4), 788-800.

Ibrahim, I. A., \& Faramita, R. (2015). Hubungan faktor sosial ekonomi keluarga dengan kejadian stunting anak usia 24-59 bulan di wilayah kerja puskesmas Barombong kota Makassar tahun 2014. Al-Sihah: Public Health Science Journal, 7(1), 63-75. http://103.55.216.55/index.php/Al-Sihah/ article/view/1978.

Karundeng, L., Ismanto, A., \& Kundre, R. (2015). Hubungan Jarak Kelahiran Dan Jumlah Anak Dengan Status Gizi Balita Di Puskesmas Kao Kecamatan Kao Kabupaten Halmahera Utara. Jurnal Keperawatan UNSRAT, 3(1), 114321.

Kementerian Pertanian, B. K. P. (2016). Strategi Peningkatan Ketahanan Pangan Rumah Tangga Rawan Pangan. Analisis Kebijakan Pertanian, 6(3). https://doi. org/10.21082/akp.v6n3.2008.239-255.

Khomsan, A., Riyadi, H., \& Marliyati, S. A. (2013). Ketahanan Pangan Dan Gizi Serta Mekanisme Bertahan Pada 
Masyarakat Tradisional Suku Ciptagelar Di Jawa Barat. Jurnal Ilmu Pertanian Indonesia, 18(3), 186-193.

Lemeshow, S., Ogston, S. A., Hosmer, D. W., Klar, J., \& Lwanga, S. K. (1997). Adequacy of Sample Size in Health Studies. Biometrics, 47(1). https://doi. org/10.2307/2532527.

Masrin, Paratmanitya, Y., \& Aprilia, V. (2014). Household food security correlated with stunting in children 6-23 months. Jurnal Gizi Dan Dietetik Indonesia (Indonesian Journal of Nutrition and Dietetics), 2(3), 103-115.

Mustika, W., \& Syamsul, D. (2018). Analis is Permasalahan Status Gizi Kurang Pada Balita di Puskesmas Teupah Selatan Kabupaten Simeuleu. Jurnal Kesehatan Global, 1(3), 127. https://doi.org/ 10.33085/jkg.v1i3.3952.

Musyayadah, \& Adiningsih, S. (2019). Hubungan ketahanan pangan keluarga dan frekuensi diare dengan stunting pada balita di kampung surabaya the relationship between family food security and the frequency of diarrhea among stunted toddlers in kampung surabaya. Amerta Nutrition, 3(4), 257-262. https://doi.org/10.2473/amnt.v3i4.2019.

Ni'mah., C., \& Lailatul, M. (2015). Hubungan Tingkat Pendidikan, Tingkat Pengetahuan dan Pola Asuh Ibu dengan Wasting dan Stunting pada Balita Keluarga Miskin. Media Gizi Indonesia, 10(2015), 84-90. https://doi.org/Vol. 10, No. 1 Januari-Juni 2015: hlm. 84-90 terdiri.

Nirmala, S., Riski, M., \& Ratnawati, L. Y. (2018). Hubungan Pengetahuan Ibu tentang Pola Pemberian Makan dengan
Status Gizi Balita di Wilayah Kerja Puskesmas Gapura Kabupaten Sumenep. Amerta Nutrition, 2(2), 182. https://doi. org/10.20473/amnt.v2i2.2018. 182-188

Omotesho, O., Adewumi, M., \& Fadimula, K. (2019). Food security and poverty of the rural households in Kwara State, Nigeria. AAAE Conference Proceedings, 571575.

Prasetyo, T. J., Hardinsyah, \& Sinaga, T. (2013). Konsumsi Pangan Dan Gizi Serta Skor Pola Pangan Harapan ( Pph ). Jurnal Gizi Dan Pangan, 8(November), 159-166.

Rahmawati, L. A., Hardy, F. R., Anggraeni, A., \& Purbasari, D. (2020). Faktor-Faktor yang Berhubungan dengan Stunting Sangat Pendek dan Pendek pada Anak Usia 24-59 Bulan di Kecamatan Sawah Besar Related Factors of Very Short and Short Stunting In Children Aged 24 - 59 Months in Kecamatan Sawah Besar. Jurnal Ilmiah Kesehatan Masyarakat, 12(2), 68-78.

Riskesdas. (2018). Hasil Utama Riset Kesehatan Dasar. Kementrian Kesehatan Republik Indonesia. https://doi.org/1 Desember 2013.

Sihite, N. W., \& Tanziha, I. (2021). Faktorfaktor yang mempengaruhi ketahanan pangan rumah tangga di Kota Medan. AcTion: Aceh Nutrition Journal, 6(1), 15. https://doi.org/10.30867/action.v6i1.395.

Tanziha, I. (2011). Model Pemberdayaan Petani Menuju Ketahanan Pangan Keluarga. Jurnal Gizi Dan Pangan. https ://doi. org/10.25182/jgp.2011.6.1.9099. 